\title{
New K-Ar ages of the Society Islands, French Polynesia, and implications for the Society hotspot feature
}

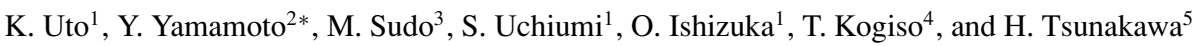 \\ ${ }^{1}$ Geological Survey of Japan, AIST, Tsukuba, Ibaraki 305-8567, Japan \\ ${ }^{2}$ Geomagnetism Laboratory, University of Liverpool, Oliver Lodge Laboratories, Oxford Street, Liverpool, L69 7ZE, United Kingdom \\ ${ }^{3}$ Institute of Earth Sciences, University of Potsdam, Karl-Liebknechtstrasse 24, Haus 25, 14476 Golm, Germany \\ ${ }^{4}$ Institute for Research on Earth Evolution (IFREE), JAMSTEC, Kanagawa 237-0061, Japan \\ ${ }^{5}$ Department of Earth and Planetary Sciences, Tokyo Institute of Technology, Tokyo 152-8551, Japan
}

(Received October 2, 2006; Revised January 29, 2007; Accepted January 29, 2007; Online published July 20, 2007)

\begin{abstract}
We report 52 new K-Ar age determinations of volcanic rocks from the Society Islands in French Polynesia. The newly obtained ages range from 0.51 to $4.61 \mathrm{Ma}$, which are consistent with previously reported ones. The magnetostratigraphy based on 45 data sets combining K-Ar ages and paleomagnetic polarity agrees with the geomagnetic polarity time scale at the $2 \sigma$ level, except for a few age data. Assuming the absolute motion of the Pacific plate, paleopositions of the dated rocks are estimated from the K-Ar ages, showing a narrow distribution in the western part of the easternmost volcano of the active hotspot region. This suggests that a hotspot of a few tens of kilometers in diameter might have been fixed nearly at the eastern margin of the presently active region in the Society archipelago and that the volcanism of each island might have persisted for about 1 myr.
\end{abstract}

Key words: K-Ar ages, Society Islands, magnetostratigraphy, hotspot, paleoposition.

\section{Introduction}

Systematic radioisotopic dating of hotspot volcanic rocks is able to provide semi-continuous information on the ancient Earth's activity, such as volcanism, plate motion, and geomagnetic fields. The Society archipelago is one of the hotspot volcanic chains in the Pacific Ocean (e.g. Duncan and McDougall, 1976), comprising more than ten islands and atolls, among which volcanic edifices emerge above sea level in nine islands (Fig. 1). The island chain is elongated in the $\mathrm{N} 65^{\circ} \mathrm{W}$ direction, which is virtually parallel to the present absolute motion of the Pacific plate (Gripp and Gordon, 1990). The geology, geochemistry, and geochronology of the Society Islands have been studied and discussed by many researchers (e.g. Blais et al., 1997, 2000; Duncan and McDougall, 1976; Duncan et al., 1994; Dymond, 1975; Hildenbrand et al., 2004; Guillou et al., 1998, 2005; Kogiso et al., 1997; Singer et al., 1999; White and Duncan, 1996).

The ages of the volcanic islands decrease toward the southeast, from about $5 \mathrm{Ma}$ at Maupiti (e.g. Duncan and McDougall, 1976) to $0 \mathrm{Ma}$ at Mehetia (e.g. Binard et al., 1993). Published $\mathrm{K}-\mathrm{Ar}$ and ${ }^{40} \mathrm{Ar} /{ }^{39} \mathrm{Ar}$ ages are in the ranges of 4.79-4.05 Ma for Maupiti, 3.83-3.10 Ma for Bora Bora, 3.39-1.10 Ma for Tahaa, 2.75-2.29 Ma for Raiatea, 3.082.06 Ma for Huahine, 2.15-1.36 Ma for Moorea, and 1.670.25 Ma for Tahiti (Dymond, 1975; Duncan and MacDougall, 1976; Roperch and Duncan, 1990; Duncan et al.,

\footnotetext{
*Now at Center for Advanced Marine Core Research, Kochi University B200 Monobe, Nankoku, Kochi 783-8502, Japan.

Copyright (c) The Society of Geomagnetism and Earth, Planetary and Space Sciences (SGEPSS); The Seismological Society of Japan; The Volcanological Society of Japan; The Geodetic Society of Japan; The Japanese Society for Planetary Sciences; TERRAPUB
}

1994; White and Duncan, 1996; Guillou et al., 2005 and reference therein). Active volcanic events have been seismically detected at some seamounts around Mehetia (e.g. Talandier and Okal, 1984), suggesting that the Society hotspot is currently located there (e.g. Cheminée et al., 1989).

About 200 paleomagnetic data sets (Duncan, 1975; Chauvin et al., 1990; Roperch and Duncan, 1990) have been also reported with $17 \mathrm{~K}$-Ar ages. However, there have been insufficient data for the precise magnetostratigraphy of volcanic rocks in the Society Islands, with the exception of the Brunhes-Matuyama boundary (Singer et al., 1999; Chauvin et al., 1990). Yamamoto et al. (2002) recently reported 130 new paleomagnetic direction data from seven islands of the Society: Maupiti, Bora Bora, Tahaa, Raiatea, Huahine, Moorea, and Tahiti. Yamamoto and Tsunakwa (2005) obtained the paleointensity data of the geomagnetic field from the same set of paleomagnetic samples.

We report here 52 new K-Ar age determinations for the same rock samples as those used in the paleomagnetic studies by Yamamoto et al. (2002) and Yamamoto and Tsunakawa (2005). We discuss the magnetostratigraphy of the Society Islands during the last 5 myr and a possible feature of the Society hotspot based on the ages obtained in this study.

\section{Sampling Sites}

We selected samples for K-Ar dating mainly from the paleomagnetic samples of Yamamoto et al. (2002) with the aim of estimating the upper and lower limits of the formation ages of the sampling sites and the ages of polarity change boundaries: for example, the top and bottom lavas of the sequence. In total, we selected 54 samples of lava 


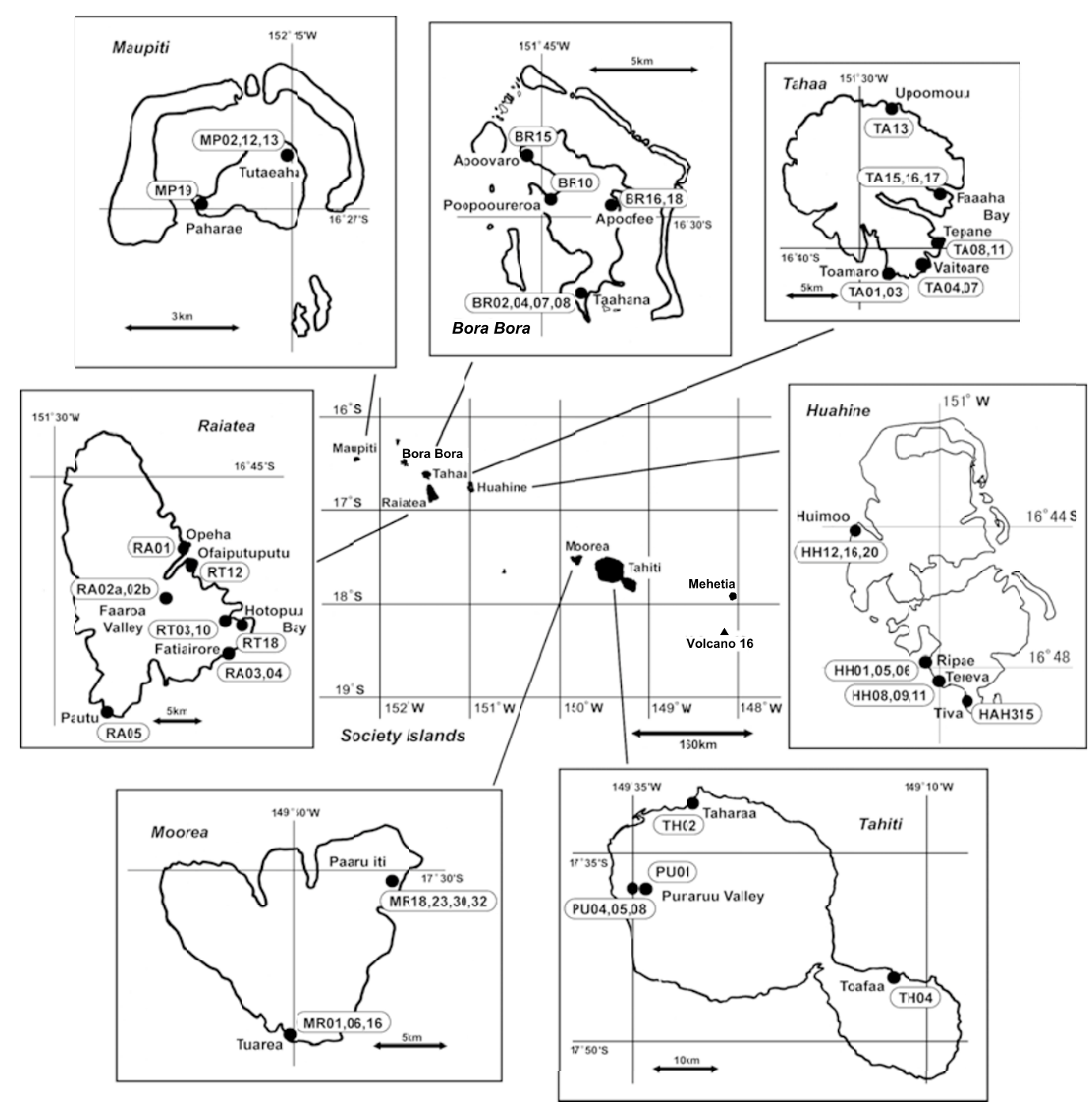

Fig. 1. Map of site locations for the rocks dated in this study. Detail descriptions are given in the text.

flows and dike intrusions for K-Ar analyses from seven islands of the Society hotspot chain: six from Tahiti, seven from Moorea, nine from Huahine, ten from Raiatea, ten from Tahaa, eight from Bora Bora, and four from Maupiti (Fig. 1). These samples were collected from the same unit, partly the same specimens, as in the paleomagnetic study by Yamamoto et al. (2002). In the following sections, we give a brief description of sample occurrences with paleomagnetic polarities according to Yamamoto et al. (2002), where the intermediate direction corresponds to a virtual geomagnetic pole (VGP) latitude between $-50^{\circ}$ and $50^{\circ}$.

\subsection{Maupiti}

Maupiti, the oldest volcanic island of the Society Archipelago, consists mainly of highly eroded shield-stage basaltic lava piles (Blais et al., 2002; Guillou et al., 2005). Four samples of basaltic rocks (MP02, MP12, MP13 and MP19) were selected from two localities. A pile of 12 thin aa lava flows of the shield stage is exposed at Haranai Valley near Tutaeaha, the northeastern end of the island. No visible evidence of a time gap, such as soil, was observed within this sequence. All of the lavas have similar paleomagnetic directions of normal polarity (Yamamoto et al., 2002), suggesting a relatively rapid accumulation of lava flows. Three samples were selected from the lava flow sequence: MP02 from the bottom, and MP13 and MP12 from the topmost and second flows. One dike rock (MP19) was selected from a dike swarm exposed at Terei'a varua point, the western end of the island, which corresponds to the $\mathrm{Pa}$ harae strombolian cone of Blais et al. (2002).

\subsection{Bora Bora}

Bora Bora is a highly eroded shield volcano comprised mainly of basaltic lavas intersected by post-shield dikes (Blais et al., 2000; Guillou et al., 2005). Eight samples (BR02, BR04, BR07, BR08, BR10, BR15, BR16, and BR18) were selected from four localities within the shieldstage lava flows. Four samples (BR02, BR04, BR07, and BR08) were taken along the shore of Taahana bay, where some thin aa lava flows cut by a few dikes are exposed behind a hotel construction site. Four lava flows and three dikes were measured for paleomagnetic directions. All of the lava flows showed reversed paleomagnetic polarity, while the dikes gave normal polarity measurements that could be grouped into two distinct directions. Two lava flow samples (BR04 and BR07) and two dike rocks (BR02 and BR08) were selected for the age determinations. South of Apoofee point, there is an outcrop along the road at the 
eastern shore where four consecutive aa lava flows are intruded by two dikes. All of these yielded normal polarity, whose directions were indistinguishable at a 95\% significance level. The bottom lava flow (BR18) and a dike rock (BR16) were chosen for the age determinations. BR15 is a lava flow with reversed polarity collected from Apoovaro, located at the northwestern shore. BR10, with normal polarity, is one of four dikes intruding into a single lava flow exposed behind a power plant to the north of Poopooureroa in the western part of the island.

\subsection{Tahaa}

Tahaa consists of shield-stage basaltic rocks of about 3 Ma and highly undersaturated lavas of the post-erosional stage erupted after a hiatus of 1.2 Ma (White and Duncan, 1996). Ten samples (TA01, TA03, TA04, TA07, TA08, TA11, TA13, TA15, TA16, and TA17) were selected from five outcrops, probably of the shield stage. Lava flows on the southern coast show intermediate paleomagnetic directions. TA03 and TA01 were taken from the top and the bottom flows of three successive lava flows at Toamaro point, and TA07 and TA04 were from the top and bottom of four lava flows to the east of Vaitoare. A definitive paleomagnetic direction was not obtained from TA01 due to weak and unstable magnetizations. TA08 and TA11 were collected from the top and bottom of the lava succession with reversed polarity at Tepane point. TA15, TA16, and TA17 were taken from a lower part of a lava sequence with normal polarity in the south shore of Faaaha Bay, near Maropau point. TA13 was collected from an isolated lava flow with reversed polarity to the east of Upoomouu in the northern part of the island.

\subsection{Raiatea}

Raiatea, the second largest island in the Society archipelago, consists of shield-stage basaltic and postshield trachytic lava flows (Guillou et al., 2005 and references therein). Ten samples of the shield-stage basalts (RA01, RA02a, RA02b, RA03, RA04, RA05, RT03, RT10, RT12, and RT18) were selected from seven localities. RA01 and RT12, with normal polarity, were located at Opeha point and Maraeroa point on the eastern coast, respectively. At the roadside outcrop in the Faaroa Valley, south-central part of the island, there is a massive lava flow (RA02a) intruded by three low-angle dikes or sills (RA02b); the samples from which gave no definitive paleomagnetic directions. At a large quarry facing Hotopuu Bay, a sequence of lava flows with normal to intermediate paleomagnetic directions is intruded by seven vertical dikes with normal polarity. Magnetization of lava flow RT10 shows an almost threshold direction between normal and intermediate ones, while RT03 is from one of the seven dikes with normal polarity. Lava flow RT18, with a normal polarity, is located a few hundred meters east of this quarry. At Fatiairore point on the south shore, there are many lava flows with thin massive part, thick aa clinkers, and/or tuff breccia, which are cut by two dikes. RA03 and RA04 were collected from the lava and the dike, respectively, yielding no meaningful paleomagnetic directions. RA05, with normal polarity, was collected from a lava flow at Pautu point on the southwestern shore.

\subsection{Huahine}

Huahine has two coalesced volcanoes, Huahine Nui (north) and Huahine Iti (south). Both volcanoes consist of shield-stage basaltic lavas and post-shield trachyphonolitic lava domes (Legendre et al., 2002). Ten samples from four sites (HH01, HH05, HH06, HH08, HH09, HH11, HH12, $\mathrm{HH} 16, \mathrm{HH} 20$, and HAH315) were selected for the age determinations. A lava sequence of more than six aa flows cut by four vertical dikes is exposed west of Huimoo point on the western shore of Huahine Nui; all of the flows and dikes of these showed normal polarity. For dating purposes, HH16 and HH20 were taken from the top flow and the fourth flow of the lava sequence, respectively, while HH12 was from the dike. Along the southwestern shoreline of Huahine Iti, the outcrop at Ripae point consists of several successive lava flows and three dikes, all of which showed normal polarity. Samples from one lava flow (HH01) and two dikes (HH05 and HH06) have statistically distinguishable paleomagnetic directions; consequently, these were selected for age determinations. The outcrop at Tereva point (HH08, HH09, and HH11) consists of a few lava flows and a dike, and two weathered layers are interbedded in the lava sequence. HH09 was taken from the bottom flow beneath a thin weathered layer, while HH11 was from the flow just above tuff breccia overlying the other thick weathered layer of soil. It should be noted that a few lava flows are intercalated between two weathered layers. HH08 was taken from the dike cutting all of the lavas. All of these three sites showed normal polarity, although the paleomagnetic direction of HH09 is statistically distinct from those of HH11 and HH08. At Tiva point on the southernmost part of the island, a thick lava of trachyphonolite (HAH315) exists which represents the post-shield volcanic activity of Huahine; samples from this site were not used in the paleomagnetic study.

\subsection{Moorea}

Moorea consists of shield-stage basaltic lavas and several units of post-shield differentiated lavas (Guillou et al., 2005). Seven samples (MR01, MR06, MR16, MR18, MR23, MR30, and MR32) were selected from two lava sequences of the shield stage. There is a sequence of thin aa lava flows with no erosion gap and/or soil at Tuarea point, located on the southern coast of the island. Seventeen successive flows were sampled for the paleomagnetic study. Since all the flows showed similar paleomagnetic directions of reversed polarity, they are thought to have been emplaced within a relatively short duration. Samples for dating were from the top flow (MR01), the sixth flow (MR06), and the sixteenth flow (MR16). A sequence of lava flows is exposed at the southeastern flank of Paaru iti on the northeastern part of the island. Sixteen lava flows were sampled for the paleomagnetic study, resulting in relatively scattered paleomagnetic directions of reversed polarity; four of these were selected for age determinations: MR18 from the top lava flow non-conformably overlies the lower flows, MR23 from a lava flow in the middle part of the section, and MR30 and MR32 from lava flows close to the bottom.

\subsection{Tahiti}

Tahiti, the largest island of the Society archipelago, is constructed of two volcanoes-Tahiti Nui and Tahiti Itiboth of which are shield volcano comprising predominantly 
Table 1. K-Ar dating results of the Society volcanic rocks. H after the site ID indicates that the sample was leached by HCl before the analysis. Occurence, lava flow (L), lava sequence (LS) and dike (D); rock type, clinopyroxene (px), olivine (ol), plagioclase (pl); Lat, Long, latitude and longitude of the sampling site; Lab No., measurement ID in the laboratory; ${ }^{40} \mathrm{Ar}$ rad, amount of radiogenic ${ }^{40} \mathrm{Ar}$; Atm Ar, percent ratio of nonradiogenic ${ }^{40} \mathrm{Ar}$; Age, determined K-Ar age with its standard deviation; Pol., paleomagnetic polarity (Yamamoto et al., 2002). Note that prefixes of Lab No. indicate radiogenic ${ }^{40} \mathrm{Ar}$ determining methods (KA and SPG: isotope dilution method; PKA: sensitivity method). Ages of HH09 and MR18 are considered as anomalous (see the text).

\begin{tabular}{|c|c|c|c|c|c|c|c|c|c|c|c|c|}
\hline \multirow{2}{*}{$\begin{array}{l}\text { Site ID. } \\
\text { Maupiti }\end{array}$} & \multirow[t]{2}{*}{ occurrence } & \multirow[t]{2}{*}{ rock type } & \multirow[t]{2}{*}{ Lat } & \multirow[t]{2}{*}{ Long } & \multirow[t]{2}{*}{ Lab No. } & \multirow[t]{2}{*}{$\begin{array}{c}\mathrm{K}_{2} \mathrm{O} \\
\text { (wt. \%) }\end{array}$} & \multirow[t]{2}{*}{$\begin{array}{c}{ }^{40} \mathrm{Ar} \mathrm{rad} \\
\left(10^{-6} \mathrm{mlSTP} / \mathrm{g}\right)\end{array}$} & \multirow[t]{2}{*}{$\begin{array}{c}\text { Atm.Ar } \\
(\%)\end{array}$} & \multicolumn{3}{|c|}{$\begin{array}{c}\operatorname{Age}( \pm 1 \sigma) \\
(\mathrm{Ma})\end{array}$} & Pol. \\
\hline & & & & & & & & & & & & \\
\hline MP13 & & px-ol-basalt & & & KA2683 & 2.07 & 0.309 & 31.4 & 4.61 & \pm & 0.05 & $\mathrm{~N}$ \\
\hline MP12 & \}$_{\text {LS }}$ & px-ol-basalt & -16.437 & -152.252 & KA2684 & 1.63 & 0.240 & 40.8 & 4.55 & \pm & 0.05 & $\mathrm{~N}$ \\
\hline MP02H & & ol-px-basalt & & & PKA01045 & 1.76 & 0.257 & 18.3 & 4.52 & \pm & 0.05 & $\mathrm{~N}$ \\
\hline MP19H & D & pl-ol-basalt & -16.452 & -152.275 & PKA01048 & 1.85 & 0.270 & 49.2 & 4.52 & \pm & 0.05 & $\mathrm{~N}$ \\
\hline Bora Bora & & & & & & & & & & & & \\
\hline BR07 & & px-ol-basalt & & & KA2706 & 1.12 & 0.133 & 49.8 & 3.67 & \pm & 0.05 & $\mathrm{R}$ \\
\hline BR04 & \} $\mathrm{LS}$ & ol-basalt & & & KA2705 & 1.90 & 0.230 & 42.4 & 3.75 & \pm & 0.05 & $\mathrm{R}$ \\
\hline $\mathrm{BR} 02 \mathrm{H}$ & $\mathrm{D}$ & aphyric basalt & -16.536 & -151.733 & KA2733 & 1.07 & 0.111 & 60.8 & 3.21 & \pm & 0.09 & $\mathrm{~N}$ \\
\hline BR08H & D & pl-px-basalt & & & KA2734 & 1.93 & 0.210 & 49.2 & 3.37 & \pm & 0.05 & $\mathrm{~N}$ \\
\hline BR15 & $\mathrm{L}$ & px-ol-basalt & -16.474 & -151.759 & KA2707 & 1.30 & 0.144 & 55.0 & 3.43 & \pm & 0.06 & $\mathrm{R}$ \\
\hline BR18 & $\mathrm{L}$ & ol-basalt & & & KA2718 & 1.21 & 0.137 & 54.8 & 3.51 & \pm & 0.05 & $\mathrm{~N}$ \\
\hline BR16 & & ankaramite & \}-16.496 & -151.731 & KA2708 & 2.01 & 0.214 & 36.2 & 3.30 & \pm & 0.06 & $\mathrm{~N}$ \\
\hline BR10H & D & ol-basalt & -16.493 & -151.750 & KA2736 & 0.585 & 0.0757 & 61.1 & 4.01 & \pm & 0.31 & $\mathrm{~N}$ \\
\hline Tahaa & & & & & & & & & & & & \\
\hline TA03 & & px-ol-basalt & & & KA2692 & 1.64 & 0.151 & 76.0 & 2.85 & \pm & 0.06 & I \\
\hline TA01 & \} LS & ol-basalt & \} -16.684 & -151.478 & KA2691 & 1.79 & 0.181 & 43.9 & 3.14 & \pm & 0.06 & N/A \\
\hline TA07 & & px-ol-basalt & & & KA2694 & 1.11 & 0.115 & 62.9 & 3.24 & \pm & 0.05 & I \\
\hline TA04 & \} $\mathrm{LS}$ & ol-px-basalt & -16.677 & -151.454 & KA2693 & 1.34 & 0.132 & 43.8 & 3.04 & \pm & 0.04 & I \\
\hline TA11 & & ol-px-basalt & & & KA2703 & 0.472 & 0.0391 & 84.1 & 2.57 & \pm & 0.13 & $\mathrm{R}$ \\
\hline TA08 & $\xi \mathrm{LS}$ & ol-px-basalt & -16.662 & -151.444 & KA2695 & 1.78 & 0.180 & 62.2 & 3.14 & \pm & 0.06 & $\mathrm{R}$ \\
\hline TA17H & & ol-basalt & & & KA2732 & 2.97 & 0.286 & 48.9 & 2.99 & \pm & 0.04 & $\mathrm{~N}$ \\
\hline TA16 & LS & px-pl-basalt & -16.635 & -151.443 & KA2704 & 2.43 & 0.233 & 43.2 & 2.97 & \pm & 0.04 & $\mathrm{~N}$ \\
\hline TA15 & & px-pl-basalt & & & KA2731 & 2.60 & 0.243 & 61.3 & 2.90 & \pm & 0.05 & $\mathrm{~N}$ \\
\hline TA13H & $\mathrm{L}$ & ol-px-basalt & -16.584 & -151.486 & PKA01047 & 0.971 & 0.0975 & 24.5 & 3.11 & \pm & 0.04 & $\mathrm{R}$ \\
\hline Raiatea & & & & & & & & & & & & \\
\hline RT10H & $\mathrm{L}$ & aphyric basalt & & & PKA01037 & 1.63 & 0.146 & 44.1 & 2.77 & \pm & 0.04 & I \\
\hline & & & & & SPG135 & 1.63 & 0.145 & 46.6 & 2.75 & \pm & 0.03 & \\
\hline & & & -16.849 & -151.367 & & & & & 2.76 & \pm & 0.03 & \\
\hline RT03H & D & aphyric basalt & & & PKA01041 & 1.93 & 0.165 & 75.2 & 2.65 & \pm & 0.03 & $\mathrm{~N}$ \\
\hline RT12H & $\mathrm{L}$ & ankaramite & -16.810 & -151.393 & PKA01040 & 2.08 & 0.175 & 27.5 & 2.61 & \pm & 0.03 & $\mathrm{~N}$ \\
\hline RT18H & $\mathrm{L}$ & ol-px-basalt & -16.849 & -151.359 & PKA01039 & 1.63 & 0.141 & 23.8 & 2.67 & \pm & 0.03 & $\mathrm{~N}$ \\
\hline RA01 & $\mathrm{L}$ & px-ol-basalt & -16.800 & -151.399 & KA2575 & 1.14 & 0.0900 & 54.7 & 2.45 & \pm & 0.05 & $\mathrm{~N}$ \\
\hline RA02a & $\mathrm{L}$ & ankaramite & & & KA2582 & 1.86 & 0.157 & 59.7 & 2.62 & \pm & 0.04 & N/A \\
\hline RA02b & $\mathrm{D}$ & ankaramite & -16.834 & -151.416 & KA2583 & 2.04 & 0.175 & 54.1 & 2.67 & \pm & 0.04 & N/A \\
\hline RA03 & $\mathrm{L}$ & px-pl-basalt & & & KA2584 & 1.41 & 0.124 & 58.4 & 2.72 & \pm & 0.05 & N/A \\
\hline RA04 & D & ankaramite & \} -16.876 & \}-151.367 & KA2586 & 1.39 & 0.114 & 54.3 & 2.55 & \pm & 0.03 & N/A \\
\hline RA05 & $\mathrm{L}$ & px-basalt & -16.917 & -151.455 & KA2585 & 1.38 & 0.116 & 79.9 & 2.60 & \pm & 0.07 & $\mathrm{~N}$ \\
\hline Huahine & & & & & & & & & & & & \\
\hline HH01 & $\mathrm{L}$ & ol-basalt & & & KA2630 & 1.85 & 0.162 & 46.1 & 2.72 & \pm & 0.03 & $\mathrm{~N}$ \\
\hline HH05 & D & ol-basalt & -16798 & -151.008 & KA2631 & 1.95 & 0.169 & 48.4 & 2.68 & \pm & 0.04 & $\mathrm{~N}$ \\
\hline HH06 & D & ol-basalt & & & KA2637 & 2.17 & 0.181 & 39.1 & 2.58 & \pm & 0.05 & $\mathrm{~N}$ \\
\hline HH11 & & ol-basalt & & & KA2633 & 2.31 & 0.231 & 43.2 & 3.09 & \pm & 0.04 & $\mathrm{~N}$ \\
\hline HHO9* & \} LS & ol-basalt & 6.806 & & KA2638 & 1.23 & 0.160 & 44.8 & $(4.01$ & \pm & $0.05)$ & $\mathrm{N}$ \\
\hline HH08 & D & ol-basalt & & & KA2632 & 1.37 & 0.141 & 37.0 & 3.19 & \pm & 0.13 & $\mathrm{~N}$ \\
\hline $\mathrm{HH} 20$ & $\mathrm{~L}$ & ol-basalt & & & KA2636 & 1.56 & 0.143 & 50.7 & 2.83 & \pm & 0.09 & $\mathrm{~N}$ \\
\hline HH12 & D & aphyric basalt & \} -16.736 & -151.041 & KA2635 & 1.40 & 0.114 & 56.2 & 2.52 & \pm & 0.04 & $\mathrm{~N}$ \\
\hline НАН315 & $\mathrm{L}$ & trachyphonolite & -16.813 & -150.985 & KA2666 & 5.50 & 0.358 & 28.0 & 2.02 & \pm & 0.03 & - \\
\hline Moorea & & & & & & & & & & & & \\
\hline MR01 & & ankaramite & & & KA2749 & 1.43 & 0.0730 & 69.7 & 1.58 & \pm & 0.04 & $\mathrm{R}$ \\
\hline MR06 & $\xi_{\text {LS }}$ & ankaramite & -17.590 & -149.839 & KA2748 & 1.31 & 0.0686 & 78.6 & 1.62 & \pm & 0.08 & $\mathrm{R}$ \\
\hline MR16 & & ankaramite & & & KA2747 & 1.38 & 0.0672 & 77.9 & 1.51 & \pm & 0.04 & $\mathrm{R}$ \\
\hline MR18* & & px-ol-benmoreite & & & KA2750 & 4.75 & 0.270 & 32.7 & $(1.76$ & \pm & $0.04)$ & N/A \\
\hline MR23 & & ankaramite & & & KA2751 & 1.23 & 0.0618 & 86.0 & 1.55 & \pm & 0.06 & $\mathrm{R}$ \\
\hline MR30 & \} $\mathrm{LS}$ & ol-px-basalt & -17.501 & -149.769 & KA2753 & 3.78 & 0.186 & 31.9 & 1.53 & \pm & 0.02 & N/A \\
\hline MR32 & & ankaramite & & & KA2752 & 1.15 & 0.0559 & 75.2 & 1.50 & \pm & 0.04 & $\mathrm{R}$ \\
\hline Tahiti Nui & & & & & & & & & & & & \\
\hline PU01H & $\mathrm{L}$ & px-ol-basalt & -17.629 & -149.567 & PKA01046 & 0.687 & 0.0248 & 88.3 & 1.12 & \pm & 0.02 & $\mathrm{R}$ \\
\hline PU08 & $\mathrm{L}$ & ol-basalt & & & KA2569 & 1.04 & 0.0333 & 93.4 & 0.99 & \pm & 0.08 & $\mathrm{R}$ \\
\hline PU04 & D & ankaramite & -17.631 & -149.585 & KA2570 & 1.67 & 0.0497 & 80.2 & 0.92 & \pm & 0.03 & $\mathrm{~N}$ \\
\hline PU05 & D & px-ol-basalt & & & KA2571 & 1.31 & 0.0434 & 72.6 & 1.03 & \pm & 0.02 & $\mathrm{~N}$ \\
\hline TH02 & $\mathrm{L}$ & ol-px-basalt & -17.519 & -149.505 & KA2572 & 1.59 & 0.0371 & 81.0 & 0.72 & \pm & 0.11 & $\mathrm{~N}$ \\
\hline Tahiti Nui & & & & & & & & & & & & \\
\hline TH04 & $\mathrm{L}$ & aphyric basalt & -17.745 & -149.215 & KA2574 & 0.657 & 0.0108 & 95.1 & 0.51 & \pm & 0.10 & $\mathrm{~N}$ \\
\hline
\end{tabular}

of basaltic lava flows with subordinate differentiated rocks. Five samples from Tahiti Nui (TH02, PU01, PU04, PU05, and PU08) and one sample from Tahiti Iti (TH04) were dated in this study.

One sample (TH04) with normal polarity was collected from the aphyric basalt lava at Toafaa on the northern slope of Tahiti Iti; one sample, TH02, with normal polarity was collected from a basaltic lava flow at Taharaa from the northern slope of Tahiti Nui. Four basalt samples were also collected at the Punaruu Valley on the western slope. PU08, with reversed polarity, was collected from a lava flow cut by two dikes with normal polarity (PU04 and PU05), and PU01, with reversed polarity, was from a lava flow stratigraphically older than PU08, also with reversed polarity. Singer et al. (1999) reported paleomagnetic and geochronological studies of the lava sequence along the Punaruu Valley and found the Jaramillo subchron in the lava section near our sampling locality of PU04, PU05, and PU08. Therefore, the normal polarity of PU04 and PU05 could correspond to the Jaramillo subchron. 


\section{K-Ar Dating}

Rock samples, with no or minor alteration, were crushed into 30- to 60-mesh grains and cleaned ultrasonically. Since most samples are abundant in olivine and/or clinopyroxene phenocrysts (Table 1), fresh groundmass grains were carefully extracted using an isodynamic separator, heavy liquid, and handpicking for argon isotope analyses. Sub-samples were further ground in a triturator for potassium content measurements. Potassium contents were measured by flame emission spectrometry (FIP-3D) following peak integration and lithium internal standard methodologies (Matsumoto, 1989). Each sample was measured in triplicate, together with measurements of two standard samples (JG-1a and JB1 ), and the measurements were in good agreement (less than $1 \%$ of difference) with the optimal values by Ando et al. (1971). Concentrations of radiogenic ${ }^{40} \mathrm{Ar}$ were determined using a VG Isotopes 603 mass spectrometer by the isotope dilution method (Shibata, 1968; Uto et al., 1995) for most samples, and using a VG Isotopes $1200 \mathrm{C}$ spectrometer with the sensitivity method (Matsumoto et al., 1989) for eight samples. K-Ar ages were calculated by applying the decay constants of $\lambda_{e}=0.581\left(10^{-10} / \mathrm{yr}\right)$ and $\lambda_{\beta}=4.962\left(10^{-10} / \mathrm{yr}\right)$, and the atomic ratio ${ }^{40} \mathrm{~K} / \mathrm{K}$ of 0.0001167 (Steiger and Jäger, 1977). Errors of K-Ar ages are estimated from those obtained in determinations of potassium and radiogenic ${ }^{40} \mathrm{Ar}$ contents (Matsumoto et al., 1989; Uto et al., 1997).

Uto et al. (1997) reported that the isotope dilution method and the sensitivity method in the radiogenic measurement give concordant ages of 27.5 $\pm 0.2 \mathrm{Ma}$ (isotope dilution method) and 27.4 $\pm 0.2 \mathrm{Ma}$ (sensitivity method) for Fish Canyon Tuff biotite, which is one of the well-known age standard samples. These ages are nearly identical to the age of 27.51 Ma reported by Lanphere and Baadsgaard (2001), but about $2 \%$ younger than the age of $28.02 \pm 0.16 \mathrm{Ma}$ reported by Renne et al. (1998) that is widely accepted in $\mathrm{K}-\mathrm{Ar}$ and ${ }^{40} \mathrm{Ar} /{ }^{39} \mathrm{Ar}$ chronological studies.

The measurement results are listed in Table 1. The K-Ar ages are consistent with the geological stratigraphy, with the exception of those for samples HH09 and MR18. The age of MR18 $(1.76 \pm 0.04 \mathrm{Ma})$ is older than those of stratigraphically lower flows MR23, MR30, and MR32 (1.50$1.55 \mathrm{Ma}$ ). Many xenocrystic olivine crystals were observed in the lava flow of MR18 in the field, suggesting a possible influence of excess ${ }^{40} \mathrm{Ar}$ on the age determination, although olivine xenocrysts were removed in the experimental procedure. HH09 showed a much older age $(4.01 \pm 0.05$ Ma) than the other Huahine data (2.02-3.19 Ma), although it shows no anomalous petrographical feature. The results from these two samples are tentatively not included in the subsequent discussion.

\section{Discussion}

\subsection{Comparison with GPTS}

Combining the K-Ar dates (Table 1) and the paleomagnetic polarities (Yamamoto et al., 2002), we constructed magnetostratigraphy from 45 pairs of data sets for comparison with the geomagnetic polarity time scale (GPTS; Cande and Kent, 1995) in Fig. 2. The data sets of previous studies (18 data sets; Duncan and McDougall, 1976; Chauvin et al., 1990; Roperch and Duncan, 1990) are also

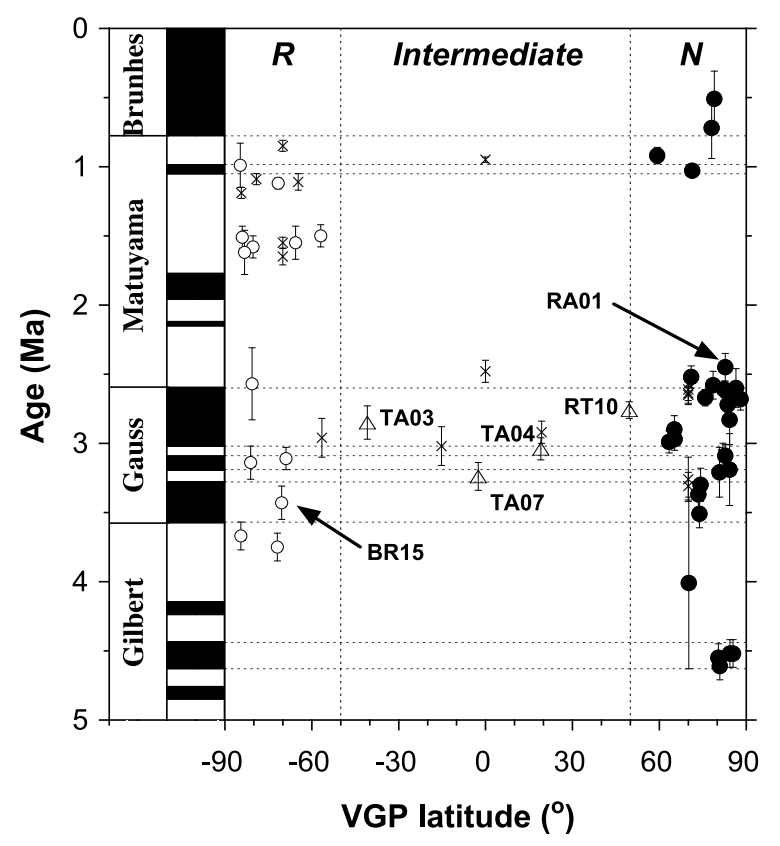

Fig. 2. Magnetostratigraphy constructed from K-Ar ages and paleomagnetic polarities of 45 lava flows and dikes in comparison with GPTS (Cande and Kent, 1995). Circles and triangles: data points in this study (solid circle, normal; open circle, reversed; triangle, intermediate). Cross: data points in previous studies (Duncan and McDougall, 1976; Chauvin et al., 1990; Roperch and Duncan, 1990). Note that the VGP latitudes of the data by Duncan and McDougallare are set to $70^{\circ}$, $0^{\circ}$, and $-70^{\circ}$ for the normal $(\mathrm{N})$, intermediate, and reversed (R) polarities, respectively, because the detailed information about paleomagnetic directions is not available. Error bars in age are at the $2 \sigma$ level.

shown in Fig. 2. With the exception of the intermediate directions $\left(-50^{\circ}<\mathrm{VGP}\right.$ latitudes $\left.<50^{\circ}\right)$ and the data from RA01 and BR15, the measurement results in our study are consistent with GPTS at the $2 \sigma$ level. Even considering $2 \sigma$ errors of the age determinations, the K-Ar ages of RA01 and BR15 are still about $0.03 \mathrm{Ma}$ apart from the nearest polarity boundaries of GPTS, which are the Matuyama-Gauss boundary of $2.58 \mathrm{Ma}$ and the Gauss-Gilbert boundary of $3.58 \mathrm{Ma}$. These differences could be explained if shortinterval events, such as excursion, were recorded. For example, RA01 K-Ar age $(2.45 \pm 0.05 \mathrm{Ma}$; Table 1$)$ is close to the age of cryptochron 2r.2r-1 (2.420-2.441; Cande and Kent, 1996). Otherwise, one or two of the $52 \mathrm{~K}$-Ar ages calculated may possibly deviate from the true formation age slightly over $2 \sigma$ level due to the statistical probability. Consequently, it is thought that the $\mathrm{K}-\mathrm{Ar}$ ages in this study have a high reliability. The intermediate directions of RT10, TA03, TA04, and TA07 in this study are further studied elsewhere (Yamamoto et al., 2007).

\subsection{Hotspot features of the Society Islands}

It has been inferred from the ages reported by the previous studies that the volcanism duration in each island was around $1 \mathrm{myr}$, as stated in Section 1 . However, the K-Ar ages in our study show a duration that is shorter than 1 myr for each island. This difference may be attributed to the fact that the samples used in the age determination could have been from the limited areas since our sampling was conducted mainly for the paleomagnetic study.

The present hotspot responsible for generating the So- 


\section{Paleopositions of the dated rocks}

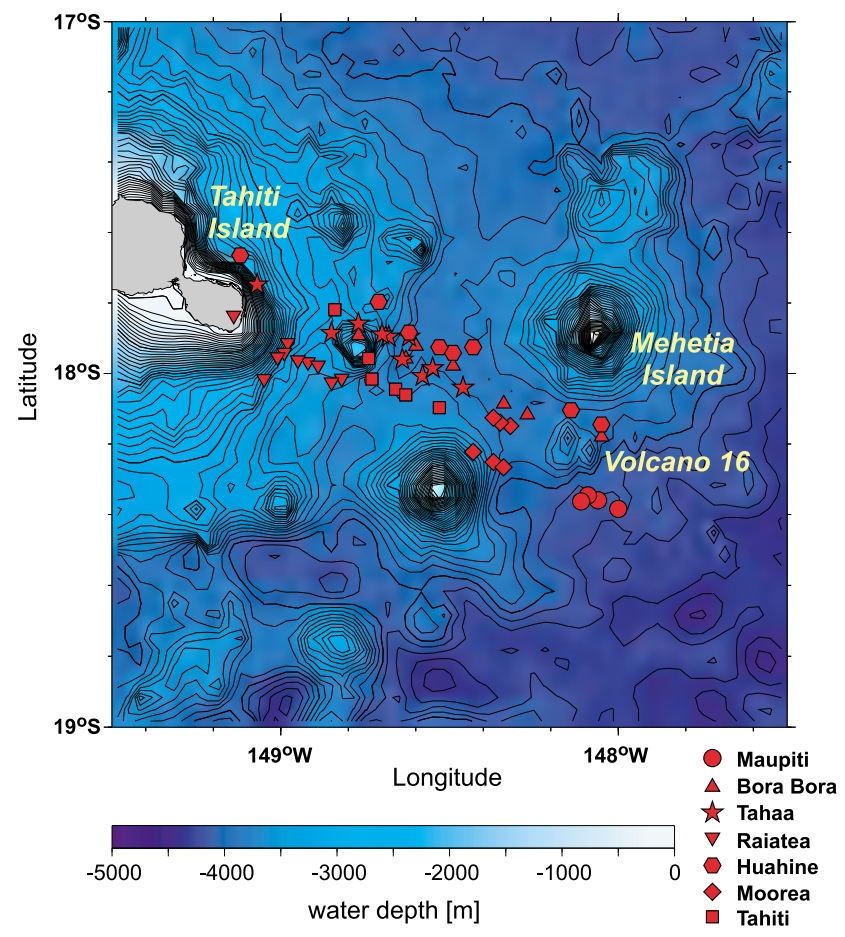

Fig. 3. Bathymetric map of paleopositions for the dated rocks in this study calculated from those K-Ar ages and the absolute motion of the Pacific plate. The lineament is almost parallel to the movement due to the Pacific-plate absolute motion at this area (Gripp and Gordon, 1990).

ciety archipelago is considered to be within an area that is about $100 \mathrm{~km}$ in diameter $\left(17.5-18.5^{\circ} \mathrm{S}, 148-149^{\circ} \mathrm{W}\right)$, where Mehetia Island and several seamounts are distributed (e.g. Binard et al., 1991, 1993). A linear increase in age WNW along the chain has been confirmed (e.g. Duncan and McDougall, 1976; Guillou et al., 2005), which is in agreement with the absolute motion of the Pacific plate; see, for example, the HS2-NUVEL1 model (Gripp and Gordon, 1990). Subaerial volcanism on the Huahine, Raiatea, and Tahaa islands occurred around $3 \mathrm{Ma}$ (Table 1). Since these islands are distributed within an area about $50 \mathrm{~km}$ in diameter, the Society hotspot region may have maintained its present size for the last 5 myr.

Assuming the absolute motion of the Pacific plate by Gripp and Gordon (1990), we have estimated the paleopositions of the dated rocks from their present positions and $\mathrm{K}$-Ar ages. If extensive volcanism occurred over the present hotspot region for the last $5 \mathrm{myr}$, the calculated paleopositions would be spread randomly in region of about $100 \mathrm{~km}$ in diameter. However, they show a relatively narrow zone that is about $30 \mathrm{~km}$ wide and about $120 \mathrm{~km}$ long (Fig. 3), extending nearly parallel to the absolute motion of the Pacific plate.

It should be examined whether or not the lineament of paleopositions is artificial due to some uncertainties, such as errors in the age and/or the plate motion. Since the estimation of the absolute motion of the Pacific plate is controlled mainly by hotspots other than the Society Islands (e.g. Gripp and Gordon, 1990), its direction can be regarded as being almost independent of the Society Islands data. This indicates that the direction of the Society chain agrees well with that of the Pacific-plate absolute motion. Although paleopositions depend on uncertainties in the Euler pole position and velocity of the Pacific-plate motion, the linear feature persists with some modifications in its direction, length, and width. Further, the lineament length of about $100 \mathrm{~km}$ corresponds to about a 1-myr time span in the Pacific-plate absolute motion of $10.8 \mathrm{~cm} /$ year (Gripp and Gordon, 1990), so that it is not explained by the representative experimental error of $\mathrm{K}$-Ar ages (approx. 0.05 $\mathrm{Ma}$ ), as shown in Table 1. Consequently, the lineament of paleopositions is not artificial but does include some information about the Society hotspot.

This lineament of paleopositions can be elucidated by a hotspot a few tens of kilometers in diameter. In this model, the subaerial volcanism of each island is assumed to have initiated above a major hotspot fixed at the eastern end of the hotspot region around Volcano 16 (Fig. 3) and the volcanic edifice is assumed to have been formed and moved apart from the hotspot due to the plate motion. However, the volcanism persisted for about a 1-myr duration or for about a distance of $100 \mathrm{~km}$ from the hotspot. It is noted that the difference of the paleoposition distribution among islands may be caused by the limited sampling areas in this study. Mechanisms for maintaining continuous volcanism over this period will be addressed in future works.

\section{Conclusions}

(1) K-Ar dating was performed for 54 basaltic samples from the Society Islands, French Polynesia. The ages obtained range between 0.51 and $4.61 \mathrm{Ma}$, which are consistent with the previously reported ages and also with the GPTS, with the exception of two anomalous data.

(2) Paleopositions of the dated rocks were estimated from those K-Ar ages, and the absolute motion of the Pacific plate. Their distribution shows a lineament in the present hotspot region of the Society, extending parallel to the Pacific-plate absolute motion, with a length corresponding to a 1-myr time span of the plate velocity. This lineament can be explained by a hotspot of a few tens of kilometers in diameter fixed at the easternmost area of the present hotspot region.

Acknowledgments. We would like to express our sincere gratitude to Hans Barsczus for his continuous help during the field work in French Polynesia. We also thank the reviewers, Robert A. Duncan and Ichiro Kaneoka, and the editor, Toshitsugu Yamazaki, for their constructive comments. Y.Y. was supported by JSPS Research Fellowships for Young Scientists in the course of this study. This study was supported from the 'Super Plume' project by the Science and Technology agency of Japan.

\section{References}

Ando, A., H. Kurasawa, T. Ohmori, and E. Takeda, 1971 compilation of data on rock standards JG-1 and JB-1 issued from the Geological Survey of Japan, Geochem. J., 5, 151-164, 1971.

Binard, N., R. Hekinian, J. L. Cheminee, R. C. Searle, and P. Stoffers, Morphological and structural studies of the Society and Austral hotspot regions in the South Pacific, Tectonophys., 186, 293-312, 1991.

Binard, N., R. C. Maury, G. Guille, J. Talandier, P. Y. Gillot, and J. Cotton, Mehetia Island, South Pacific: geology and petrology of the emerged part of the Society hot spot, J. Volcanol. Geotherm. Res., 55, 239-260, 1993. 
Blais, S., G. Guille, R. C. Maury, H. Guillou, D. Miau, and J. Cotten, Geology and petrology of Raiatea Island (Society Islands, French Polynesia), C. R. Acad. Sci. Paris, serie IIa, 324, 435-442, 1997.

Blais, S., G. Guille, H. Guillou, C. Chauvel, R. C. Maury, and M. Caroff, Geology, geochemistry and geochronology of Bora Bora island (Society Islands, French Polynesia), C. R. Acad. Sci. Paris, Earth Planet. Sci., 331, 579-585, 2000.

Blais, S., G. Guille, H. Guillou, C. Chauvel, R. C. Maury, G. Pernet, and J. Cotten, The island of Maupiti: the oldest emergent volcano in the Society hot spot chain (French Polynesia), Bull. Soc. Geol. Fr., 173, 45$55,2002$.

Cande, S. C. and D. V. Kent, Revised calibration of the geomagnetic polarity timescale for the Late Cretaceous and Cenozoic, J. Geophys. Res., 100, 6093-6095, 1995.

Chauvin, A., P. Roperch, and R. A. Duncan, Records of geomagnetic reversals from volcanic islands of French Polynesia 2. Paleomagnetic study of flow sequence (1.2-0.6 Ma) from the Island of Tahiti and discussion of reversal models, J. Geophys. Res., 95, 2727-2752, 1990.

Cheminée, J. L., R. Hékinian, J. Talandier, F. Albarède, C. W. Devey, J. Francheteau, and Y. Lancelot, Geology of an active hot spot: TeahitiaMehetia region in the South Central Pacific, Mar. Geophys. Res., 11, 27-50, 1989.

Duncan, R. A., Paleosecular variation at the Society Islands, French Polynesia, Geophys. J. R. Astr. Soc., 41, 245-254, 1975.

Duncan, R. A. and I. McDougall, Linear volcanism in French Polynesia, J. Volcanol. Geotherm. Res., 1, 197-227, 1976.

Duncan, R. A., M. R. Fisk, W. M. White, and R. L. Nielsen, Tahiti: Geochemical evolution of a French Polynesian volcano, J. Geophys. Res., 99, 24341-24357, 1994.

Dymond, J., K-Ar ages of Tahiti and Moorea, Society Islands, and implications for the hot-spot model, Geology, 3, 236-240, 1975.

Gripp, A. E. and R. G. Gordon, Current plate velocities relative to the hotspots incorporating the NUVEL-1 global plate motion model, Geophys. Res. Let., 17, 1109-1112, 1990.

Guillou, H., S. Blais, G. Guille, R. C. Maury, A. Le Dez, and J. Cotten, Age (K-Ar) and duration of the subaerial build-up of Moorea, Raiatea and Maupiti (Society Islands, French Polynesia), Geol. Fr., 3, 29-36, 1998.

Guillou, H., R. C. Maury, S. Blais, J. Cotten, C. Legendre, G. Guille, and M. Caroff, Age progression along the Society hotspot chain (French Polynesia) based on new unspiked K-Ar ages, Bull. Soc. Geol. Fr., 176, 135-150, 2005.

Hildenbrand, A., P. Y. Gillot, and I. Le Roy, Volcano-tectonic and geochemical evolution of an oceanic intra-plate volcano: Tahiti-Nui (French Polynesia), Earth Planet. Sci. Lett., 217, 349-365, 2004.

Kogiso, T., Y. Tatsumi, G. Shimoda, and H. G. Barsczus, High $\mu$ (HIMU) ocean island basalts in southern Polynesia: New evidence for whole mantle scale recycling of subducted oceanic crust, J. Geophys. Res., 102, 8085-8103, 1997.

Lanphere, M. A. and H. Baadsgaard, Precise K-Ar, ${ }^{40} \mathrm{Ar} /{ }^{39} \mathrm{Ar}, \mathrm{Rb}-\mathrm{Sr}$ and $\mathrm{U} / \mathrm{Pb}$ mineral ages from the 27.5 Ma Fish Canyon Tuff reference standar, Chem. Geol., 175, 653-671, 2001.

Legendre, C., R. C. Maury, H. Guillou, J. Cotten, C. Chauvel, M. Caroff, S. Blais, and G. Guille, Evolution géologique et péterogique de l'île de Huahine (archipel de la Société (Polynésie francaise): un volcan- bouclier intraocéanique original, Bull. Soc. Geol. Fr., 174, 15-124, 2002.

Matsumoto, A., Improvement for determination of potassium in $\mathrm{K}-\mathrm{Ar}$ dating, Bull. Geol. Surv. Jpn., 40, 65-70, 1989.

Matsumoto, A., K. Uto, and K. Shibata, K-Ar dating by peak comparison method-New technique applicable to rocks younger than $0.5 \mathrm{Ma}$, Bull. Geol. Surv. Jpn., 40(10), 565-579, 1989.

Renne, P. R., C. C. Swisher, A. L. Deino, D. B. Karner, T. L. Owens, and D. L. DePaolo, Intercalibration of Standards, Absolute Ages and Uncertainties in ${ }^{40} \mathrm{Ar} /{ }^{39} \mathrm{Ar}$ Dating, Chemical Geology, 145, 117-152, 1998.

Roperch, P. and R. A. Duncan, Records of geomagnetic reversals from volcanic islands of French Polynesia 1. Paleomagnetic study of a polarity transition in a lava sequence from the island of Huahine, J. Geophys. Res., 95, 2713-2726, 1990.

Shibata, K., K-Ar age determinations on granitic and metamorphic rocks in Japan, Geol. Surv. Jpn. Rep., 227, 1-73, 1968.

Singer, B. S., K. A. Hoffman, A. Chauvin, R. S. Coe, and M. S. Pringle, Dating transitionally magnetized lavas of the late Matuyama Chron: Toward a new ${ }^{40} \mathrm{Ar} /{ }^{39} \mathrm{Ar}$ timescale of reversals and events, J. Geophys. Res., 104, 679-693, 1999.

Steiger, R. H. and E. Jäger, Subcomission on geochronology: Convention on the use of decay constants in geo- and cosmochronology, Earth Planet. Sci. Lett., 36, 359-362, 1977.

Talandier, J. and E. Okal, The volcanoseismic swarms of 1981-1983 in the Tahiti-Mehetia Area, French Polynesia, J. Geophys. Res., 89, 11216$11234,1984$.

Uto, K., R. M. Conrey, T. Hirata, and S. Uchiumi, Improvements of the K-Ar dating system at Geological Survey of Japan-Introduction of computer-controlled mass-spectrometry and pipette spike reservoir, Bull. Geol. Surv. Jpn., 46, 239-249, 1995.

Uto, K., O. Ishizuka, A. Matsumoto, H. Kamioka, and K. Togashi, Laserheating ${ }^{40} \mathrm{Ar} /{ }^{39} \mathrm{Ar}$ dating system of the Geological Survey of Japan: system outline and preliminary results, Bull. Geol. Surv. Jpn., 48, 23-46, 1997.

White, W. M. and R. A. Duncan, Geochemistry and Geochronology of the Society Islands: New evidence for deep mantle recycling, in Earth Processes: Reading the Isotopic Code, Geophys. Monogr. Ser., vol. 95, edited by A. Basu and S. Hart, pp. 183-206, AGU, Washington D.C., 1996.

Yamamoto, Y. and H. Tsunakawa, Geomagneic field intensity during the last 5 Myr: LTD-DHT Shaw palaeointensities from volcanic rocks of the Society Islands, French Polynesia, Geophys. J. Int., 162, 79-114, 2005.

Yamamoto, Y., O. Ishizuka, M. Sudo, and K. Uto, ${ }^{40} \mathrm{Ar} /{ }^{39} \mathrm{Ar}$ ages and paleomagnetism of transitionally magnetized volcanic rocks in the Society Islands, French Polynesia: Raiatea excursion in the upper-Gauss Chron, Geophys. J. Int., 169, 41-59, 2007.

Yamamoto, Y., K. Shimura, H. Tsunakawa, T. Kogiso, K. Uto, H. G. Barsczus, H. Oda, T. Yamazaki, and E. Kikawa, Geomagnetic paleosecular variation for the past $5 \mathrm{Ma}$ in the Society Islands, French Polynesia, Earth Planets Space, 54, 797-802, 2002.

K. Uto, Y. Yamamoto, M. Sudo, S. Uchiumi, O. Ishizuka, T. Kogiso, and H. Tsunakawa (e-mail: htsuna@geo.titech.ac.jp) 